\title{
DETERMINATION OF THE FUNCTIONAL GROUPS IN ALGAE PARACHLORELLA KESSLERI BY POTENTIOMETRIC TITRATIONS
}

\author{
DANA IVÁNOVÁ ${ }^{1}$, JANA KADUKOVÁ ${ }^{2}$, \\ JANA KAVULIČOVÁ ${ }^{1}$, HEDVIGA HORVÁTHOVÁ ${ }^{2}$ \\ ${ }^{1}$ Technical University in Košice, Faculty of Metallurgy, Department of Chemistry, \\ Letná 9, Košice, 042 00, Slovak Republic (dana.ivanova@tuke.sk) \\ ${ }^{2}$ Technical University in Košice, Faculty of Metallurgy, Department of Material \\ Science, Letná 9, Košice, 042 00, Slovak Republic (jana.kadukova@tuke.sk)
}

\begin{abstract}
The acidic functional groups of the cell wall of native algae Parachlorella kessleri were evaluated by potentiometric titrations. The Gran's method was applied to determination of the total, strong, weak and very weak acidities. The total organic acidity obtained for biomass was $3.93 \mathrm{mmol} \mathrm{g}^{-1}$, the largest content belonged to the strong acidic groups $\left(2.13 \mathrm{mmol} \mathrm{g}^{-1}\right)$ together with the weak acidic carboxylic groups $(1.28$ mmol g$\left.{ }^{-1}\right)$. Very weak acidities represented by the amine groups $\left(0.52 \mathrm{mmol} \mathrm{g}^{-1}\right)$ did not exceed $14 \%$ and they formed the lowest numerous part of all acidic functional groups.
\end{abstract}

Key words: Potentiometric titrations, Gran's method, acidic functional groups, algae Parachlorella kessleri

\section{Introduction}

It is essential to understand the complex chemistry and mechanisms involved in metal biosorption in order to exploit algal biomass on an industrial scale for water, wastewater and effluent treatment (MALIK, 1999).

Metal biosorption by biomass mainly depends on the components of the cell, especially through cell surface and the spatial structure of the cell wall. Various polysaccharides, proteins and lipids existing in algal cell walls have been proved to play a very important role in metal binding. Some functional groups have been found to bind metal ions, especially carboxyl groups. There is some evidence confirming that the O-, N-, S-, or P-containing groups participate directly in binding of certain metals (WANG and CHEN, 2009).

Green algae consist of mainly cellulose and high percentage of the cell wall is proteins (10-70\%) bonded to polysaccharides forming glycoproteins (ROMERA et al., 2007). Proteins can contribute significantly to metal binding, offering the functional groups of amino acids (hydroxyl, carboxyl, sulfhydryl, amine, amide, imidazole). The cell walls of brown algae generally contain cellulose, alginic acids and sulphated polysaccharides. The predominant active groups of mentioned compounds are carboxyl and sulphate groups (ROMERA et al., 2007). Alginate and the sulphated matrix polysaccharide fucoidan constitute about $10-40 \%$ of the brown algal dry weight, $5-20 \%$ respectively. In brown algae the protein content is less than $30 \%$. Alginate and fucoidan are known for their metal binding properties whereby ion exchange between metal ions occurs (SCHIEWER and WONG, 2000; DAVIS et al., 2003). In brown algae, the carboxyl groups of alginate are more abundant than either 
carboxyl or amine groups of the proteins and are therefore likely to be the main binding sites. Sulphate groups appear to be of secondary importance (SCHIEWER and WONG, 2000; VOLESKY, 2003; DAVIS et al., 2003). Hydroxyl groups are present in all polysaccharides but they only become negatively charged at $\mathrm{pH}>10$, at lower pH hydroxyl groups play a secondary role, too (VOLESKY, 2003; DAVIS et al., 2003).

The applications of titration techniques become a powerful tool for the characterization of heterogeneous materials involved in biosorption and bioremediation processes. The acid-base titration can yield valuable specific data for further quantitative sorption work (NAJA et al., 2005).

The aim of this study is to evaluate native biomass of Parachlorella kessleri and to attempt to quantify the acidic functional groups in the cell wall of algae by potentiometric titrations. The Gran's method is applied to determine the total acidity of the functional groups, the quantity of the three types of acidities-strong, weak or very weak.

\section{Materials and methods}

\subsection{Potentiometric titrations}

For titration, $0.25 \mathrm{~g}$ of dried untreated algal biomass - Parachlorella kessleri was dispersed in $50 \mathrm{~cm}^{3}$ distilled water. An initial $\mathrm{pH}$ value was adjusted to 1.2 by addition with a known quantity of $\mathrm{HCl}$. The suspension was titrated with $0.1 \mathrm{M} \mathrm{NaOH}$ to $\mathrm{pH}$ 11.75. Similar titration was performed on a blank solution (control) without algae.

\subsection{Gran's method}

Gran's method (GRAN, 1952; ROSSOTTI and ROSSOTTI, 1965) consists on transforming a titration curve into two linear functions $G_{1}$ versus the volume of added titrant before the end-point and $\mathrm{G}_{2}$ versus the volume of added titrant after the endpoint titration. The intersections of the linear portions with the volume axis correspond to the equivalence points $\mathrm{V}_{\mathrm{a}}$ and $\mathrm{V}_{\mathrm{b}}$.

The definition of the Gran's function is as follows:

$$
\begin{array}{ll}
\mathrm{G}_{1}=\left(\mathrm{V}_{0}+\mathrm{V}\right) \cdot 10^{-\mathrm{pH}} & \text { at } \mathrm{pH}<7 \\
\mathrm{G}_{2}=\left(\mathrm{V}_{0}+\mathrm{V}\right) \cdot 10^{(\mathrm{pH}-14)} & \text { at } \mathrm{pH}>7
\end{array}
$$

where $\mathrm{V}_{0}$ - the initial sample volume $\left(\mathrm{cm}^{3}\right)$

$\mathrm{V}$ - the volume of added titrant $\left(\mathrm{cm}^{3}\right)$

The total organic acidity $\left(\mathrm{A}_{\mathrm{TO}}\right)$ of a sample can be divided into three different chemical acidic groups depending on their apparent ionization constants (NAJA et al., 2005):

- strong acidities at $\mathrm{pH}<4$

$$
\mathrm{A}_{\mathrm{S}}\left(\text { meqg }^{-1}\right)=\frac{\left(\mathrm{V}_{\mathrm{a}}-\mathrm{V}_{\mathrm{aN}}\right)}{\mathrm{m}} \cdot \mathrm{N}_{0}
$$

- weak acidities at $4<\mathrm{pH}<7$ 


$$
\mathrm{A}_{\mathrm{W}}\left(\text { meqg }^{-1}\right)=\frac{\left(\mathrm{V}_{\mathrm{e}}-\mathrm{V}_{\mathrm{a}}\right)-\left(\mathrm{V}_{\mathrm{eN}}-\mathrm{V}_{\mathrm{aN}}\right)}{\mathrm{m}} \cdot \mathrm{N}_{0}
$$

- very weak acidities at $\mathrm{pH}>7$

$$
\begin{gathered}
A_{V W}\left(\text { meqg }^{-1}\right)=\frac{\left[\left(\mathrm{V}_{\mathrm{b}}-\mathrm{V}_{\mathrm{e}}\right)-\left(\mathrm{V}_{\mathrm{bN}}-\mathrm{V}_{\mathrm{eN}}\right)\right]\left[\left(\mathrm{V}-\mathrm{V}_{\mathrm{b}}\right)-\left(\mathrm{V}_{\mathrm{N}}-\mathrm{V}_{\mathrm{bN}}\right)\right]}{\mathrm{m}} \cdot \mathrm{N}_{0} \\
\mathrm{~A}_{\mathrm{TO}}=\mathrm{A}_{\mathrm{S}}+\mathrm{A}_{\mathrm{W}}+\mathrm{A}_{\mathrm{VW}}
\end{gathered}
$$

where $\mathrm{N}_{0}$ - the normality of the base used,

$\mathrm{V}$ and $\mathrm{V}_{\mathrm{N}}$ - the total volume of the base added after titration of the sample and control, respectively,

$\mathrm{V}_{\mathrm{e}}$ - the volume of base in the end-point titration,

$\mathrm{m}$ - sample weight $(\mathrm{g})$.

The suffix $N$ corresponds to the control.

\section{Results and discussion}

The potentiometric titration curves of the untreated algae Parachlorella kessleri and the control, curves fitted by Boltzmann function are shown in Figure 1a) and Gran's plot of the sample and the control and their linearization are shown in Figure 1b). Four equivalence points were extrapolated according to the Gran's method. $\mathrm{V}_{\mathrm{aN}}$ a $V_{a}$ are the equivalence volumes determined by the acidic slopes (before the equivalence point) of the Gran's function of the control and the sample. $V_{b N} a V_{b}$ are the equivalence volumes determined by the basic slopes (after the equivalence point) of the Gran's function of the control and the sample. In addition to these equivalence points, other points indicating the endpoint of the control $\mathrm{V}_{\mathrm{eN}}$, the first and second endpoints of the sample $\mathrm{V}_{\mathrm{e} 1}$ and $\mathrm{V}_{\mathrm{e} 2}$ were determined by Boltzmann function minimizing the mean square deviations between model and experimental data.

$\mathrm{V}_{\mathrm{aN}}$ is the $\mathrm{NaOH}$ volume necessary to titrate the excess of $\mathrm{HCl}$ over the sample total acidity, $\mathrm{V}_{\mathrm{a}}-\mathrm{V}_{\mathrm{aN}}$ is the titrant volume necessary to reaction with strong acidic groups, such as phosphoric or sulfonate groups, as well as carboxylic groups linked to aromatic functions at $\mathrm{pH}<4, \mathrm{~V}_{\mathrm{e} 1}-\mathrm{V}_{\mathrm{a}}$ and $\mathrm{V}_{\mathrm{e} 2}-\mathrm{V}_{\mathrm{e} 1}$ are attributed to the ionization of carboxylic and some proteic groups at $4<\mathrm{pH}<7, \mathrm{~V}_{\mathrm{b}}-\mathrm{V}_{\mathrm{e} 2}$ is attributed to phenolic and amine groups of proteins at $\mathrm{pH}>7$ (BRUNELOT et al., 1989; NAJA et al., 2005).

The strong, weak, very weak and total acidities calculated according to Eqs. (3)(6) as well as the quantity of acidic groups for other green and brown algal cells are indicated in Table 1.

The total number of acidic groups was found $3.93 \mathrm{mmol} \mathrm{g}^{-1}$. It may be observed from the data in Table 1 that approximately $54.2 \%$ of all binding sites in the cell wall of biomass consist of strong acidic groups (phosphoric, sulfonate and carboxylic groups linked to aromatic compounds). Weak acidic sites attributed to the carboxylic groups present the third of total acidity, whereas very weak acidities of amine groups on the biomass surface represent $13.2 \%$ of all acidic groups. It could be noted that the weak acidity attributed to carboxylic and the very weak acidity to amine functions of proteins formed nearly the half of total organic acidity. 


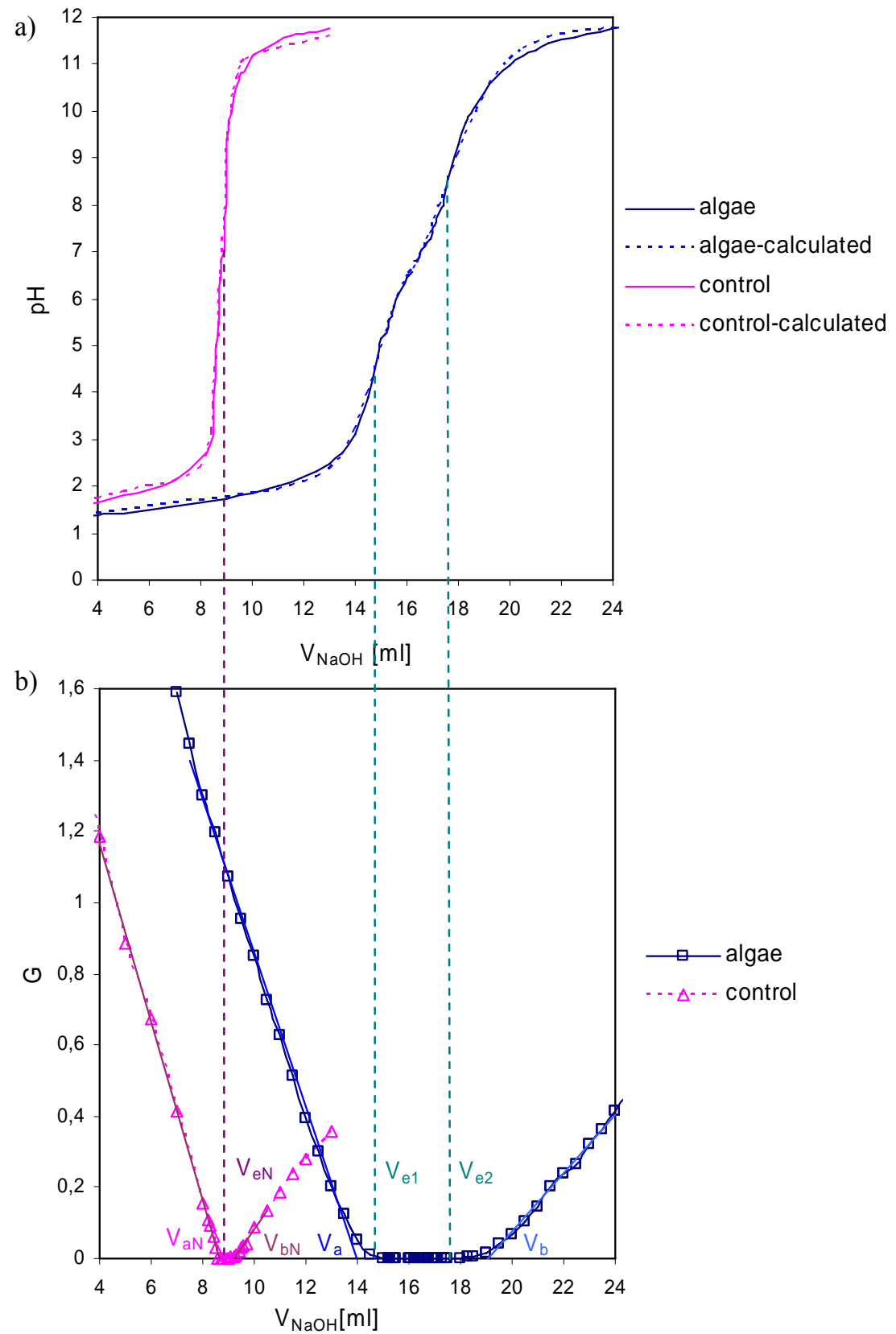

Fig. 1. a) Titration curves of a sample (untreated algae Parachlorella kessleri) and a control (without algae) and curves fitted by Boltzmann function, b) Gran's function (G) of the sample ( $\square$ ) and of the control $(\triangle)$ and their linearization. 
It appears that only content of the strong acidic sites is slightly higher in comparison with other green and brown algae whereas values of weak and very weak acidities correspond to these obtained in other studies (Table 1). The carboxylic groups are generally the most abundant acidic functional groups in the brown algae and they constitute the highest content of total acidic sites $\left(\mathrm{A}_{\mathrm{w}}\right.$ is greater than $\left.50 \%\right)$.

Table 1. Types and quantity of acidic sites for untreated algae Parachlorella kessleri and comparison with other green, brown algae.

\begin{tabular}{|c|c|c|c|c|c|c|}
\hline & \multirow{2}{*}{ Algal type } & $\mathbf{A}_{\mathbf{S}}$ & $\mathbf{A}_{\mathrm{W}}$ & $\mathbf{A}_{\mathrm{Vw}}$ & $\mathbf{A}_{\text {TO }}$ & \multirow{2}{*}{ References } \\
\hline & & \multicolumn{4}{|c|}{$\left(\mathrm{mmol} \mathrm{g}^{-1}\right)$} & \\
\hline \multirow{6}{*}{ 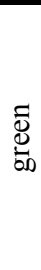 } & Parachlorella kessleri & 2.13 & 1.28 & 0.52 & 3.93 & Present work \\
\hline & Chaetophora elegans & & 0.85 & 2.99 & 3.83 & (ANDRADE et al., 2005) \\
\hline & Caulerpa scalpelliformis & & & & 2.89 & (ARAVINDHAN et al., 2007) \\
\hline & Ulva lactuca & 0.19 & 1.62 & & 1.81 & (MURPHY et al., 2007) \\
\hline & Ulva spp. & 0.44 & 1.50 & & 1.94 & (MURPHY et al., 2007) \\
\hline & Chlorella vulgaris & & 0.1 & 0.11 & 0.22 & (HADJOUDJA et al.., 2010) \\
\hline \multirow{5}{*}{ 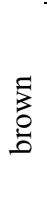 } & Fucus serratus & 1.28 & 1.93 & 0.36 & 3.56 & (AHMADY-ASBCHIN et al., 2008) \\
\hline & Sargassum vulgare & 0.5 & 1.5 & 0.75 & 2.75 & (DAVIS et al., 2000) \\
\hline & Sargassum fluitans & 0.3 & 1.5 & 0.75 & 2.55 & (DAVIS et al., 2000) \\
\hline & Sargassum filipendula & 0.3 & 1.6 & 0.80 & 2.70 & (DAVIS et al., 2000) \\
\hline & Fucus vesiculosus & & & & 2.46 & (GRIMM et al., 2008) \\
\hline
\end{tabular}

Differences in the metal biosorption capacity of mentioned green and brown algae may be attributed to differences in cell wall compounds, providing different functional groups responsible for metal biosorption (DAVIS et al., 2003). The maximum sorption capacity for copper uptake by green and brown algae is showed as comparable parameter in Table 2.

Table 2. A comparison of copper biosorption capacities for various biosorbents.

\begin{tabular}{|c|c|c|c|}
\hline & Algal type & $\frac{\mathbf{q}_{\max }}{\left(\mathrm{mg} \mathrm{g}^{-1}\right)}$ & References \\
\hline \multirow{5}{*}{ 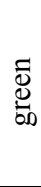 } & Parachlorella kessleri & 43 & (KADUKOVÁ and HORVÁTHOVÁ, 2011) \\
\hline & Codium vermilara & 16.9 & (ROMERA et al., 2007) \\
\hline & Spirogyra insignis & 21.3 & (ROMERA et al., 2007) \\
\hline & Ulva lactuca & 43.8 & (MURPHY et al., 2009) \\
\hline & Ulva spp. & 20.7 & (MURPHY et al., 2007) \\
\hline \multirow{5}{*}{ م } & Fucus serratus & 101.6 & (AHMADY-ASBCHIN et al., 2008) \\
\hline & Sargassum vulgare & 59.1 & (DAVIS et al., 2000) \\
\hline & Sargassum fluitans & 50.8 & (DAVIS et al., 2000) \\
\hline & Sargassum filipendula & 56.5 & (DAVIS et al., 2000) \\
\hline & Fucus vesiculosus & 23.4 & (GRIMM et al., 2008) \\
\hline
\end{tabular}

Green algae showed lower sorption capacity than brown algae. The carboxyl or amine groups of the proteins are likely to participate as main metal-binding sites in the 
green algae. On the other hand, the metal adsorption capacities of the brown algae are directly related to the presence of carboxylic groups on the alginate polymer, which counts as a significant component of the dried seaweed biomass (AHMADYASBCHIN et al., 2008; GRIMM et al., 2008).

According to the data presented in literature (DAVIS et al., 2003, MURPHY et al., 2007, GRIMM et al., 2008) it is obvious that metal uptake by both, green and brown algae, is proportional to the amount of acidic sites.

\section{Conclusions}

Polysaccharides and proteins of biomass provide various possibilities for metal binding. Titration method is subservient to indication of functional acidic groups on the surface of green algae. The total organic acidity associated with strong, weak and very weak acidic active sites was established.

In green algae Parachlorella kessleri, the quantity of strong acidic groups represents $54.2 \%$ of all binding sites in the cell wall of biomass. Weak acidic sites attributed to the carboxylic groups present $32.6 \%$ of total acidity. Very weak acidities on the biomass surface represent $13.2 \%$ of all acidic groups.

In general, in scientific literature results of biosorption or potentiometric titrations are published separately. But to understand the role of functional groups the interconnection would be very helpful. Carboxylic and amine groups of proteins could be the key functional groups of the algal cell wall responsible for metal binding within biosorption. Further research is required to understand the role of binding sites on the surface of biomass in biosorption.

Acknowledgement: This work was supported by the Slovak Grant Agency VEGA, Grant No. 1/0235/12.

\section{References}

AHMADY-ASBCHIN, S., ANDRES, Y., GÉRENTE, C., LE CLOIREC, P.: Biosorption of $\mathrm{Cu}(\mathrm{II})$ from aqueous solution by Fucus serratus: Surface characterization and sorption mechanisms. Bioresour. Technol., 99, 2008, 61506155 .

ARAVINDHAN, R., RAO, J.R., NAIR, B.U.: Removal of basic yellow dye from aqueous by sorption on green alga Caulerpa scalpelliformis. J. Hazard. Mater., $142,2007,68-76$.

BRUNElOT, G., ADRIAN, P., ROUILlER, J., GUILlET, B., ANDREUX, F.: Determination of dissociable acid groups of organic compounds extracted from soils, using automated potentiometric titration. Chemosphere, 19, 1989, 14131419.

DAVIS, T.A., VOLESKY, B., VIEIRA, R.H.S.F.: Sargassum seaweed as biosorbent for heavy metals. Water Res., 34, 2000, 4270-4278.

DAVIS, T.A., VOLESKY, B., MUCCI, A.: A review of the biochemistry of heavy metal biosorption by brown algae. Water Res., 37, 2003, 4311-4330.

GRAN, G.: Determination of the equivalence point in potentiometric titrations. Part II, Analyst, 77, 1952, 661-671. 
GRIMM, A., ZANZI, R., BJÖRNBOM, E., CUKIERMAN, A.L.: Comparison of different types of biomasses for copper biosorption. Bioresour. Technol., 99, 2008, 2559-2565.

HADJOUDJA, S., DELUCHAT, V., BAUDU, M.: Cell surface characterization of Microcystic aeruginosa and Chlorella vulgaris. J. Colloid Interface Sci., 342, 2010, 293-299.

KADUKOVÁ, J., HORVÁTHOVÁ, H.: Biosorption of copper, zinc and nickel from multi-ion solutions. Biotechnology\&Metals, $2^{\text {nd }}$ International Conference, Košice, 2011, 45-48.

MALIK, D.J., STREAT, J., GREIG, J.: Characterization and evaluation of seaweedbased sorbents for treating toxic metal-bearing solutions. Process Saf. Environ. Protect., 77, 1999, 227-233.

MURPHY, V., HUGHES, H., MCLOUGHLIN, P.: Cu(II) binding dried biomass of red, green and brown macroalgae. Water Res., 41, 2007, 731-740.

MURPHY, V., HUGHES, H., MCLOUGHLIN, P.: Enhancement strategies for Cu(II), $\mathrm{Cr}(\mathrm{III})$ and $\mathrm{Cr}(\mathrm{VI})$ remediation by variety of seaweed species. J. Hazard. Mater., $166,2009,318-326$.

NAJA, G., MUSTIN, CH., VOLESKY, B., BERTHELIN, J.: A high-resolution titrator: a new approach to studying binding sites of microbial biosorbents. Water Res., 39, 2005, 579-588.

ROMERA, E., GONZÁlEZ, F., BALLESTER, A., BLÁZQUEZ, M.L., MUÑOZ, J.A.: Comparative study of biosorption of heavy metals using different types of algae. Bioresour. Technol., 98, 2007, 3344-3353.

ROSSOTTI, F.J.C., ROSSOTTI, H.: Potentiometric titrations using Gran plots. J. Chem. Educ., 42, No. 7, 1965, 375-378.

SCHIEWER, S., WONG, M.H.: Ionic strength effects in biosorption of metals by marine algae. Chemosphere, 41, 2000, 271-282.

VOLESKY, B.: Sorption and biosorption. BV Sorbex, Inc., Montreal, 2003, 316 pp.

WANG, J., CHEN, C.: Biosorbents for heavy metals removal and their future. Biotechnol. Adv., 27, 2009, 195-226.

Presented at the 2nd International Conference "Biotechnology and Metals - 2011", September 22-23, 2011, Košice, Slovak Republic. 